\title{
Prerequisites for the creation of a tourism cluster in the Kostanay region
}

\author{
L.L. Bozhko, L.G. Leskova $\bowtie$, A.A. Mukumov \\ Rudny Industrial Institute, Rudny, Kazakhstan; lleskova@mail.ru
}

\begin{abstract}
Relevance. Under increasing competition in the market of goods and services, the structure of the national and regional economies of Kazakhstan should be modified to incorporate tourism a powerful economic driver. The formation of a viable system of geographically adjacent interconnected and mutually complementary companies is impossible without an appropriate strategy, the basis of which is a comprehensive assessment of tourism potential. Research objective. To identify prerequisites for the formation of a tourism cluster in the region based on a cluster strategy ensuring the creation of an efficient management system. Data and Methods The economy of the Kostanay region was assessed using conventional methods of economic analysis, such as grouping and comparison. The advantages and disadvantages, as well as threats and opportunities, associated with the formation of a tourism cluster in the Kostanay region were determined by SWOT analysis. The official information provided by the Bureau of National Statistics of the Agency for Strategic Planning and Reforms of the Republic of Kazakhstan was used. Results. The conducted analysis of the gross regional product of the Kostanay region and its share in the Republican volumes confirmed that the structure of the regional economy can be changed by creating a tourism cluster based on a system of interacting and complementary enterprises. The development of a tourism cluster will increase the volume of services associated with accommodation of inbound and domestic tourists. Conclusion. The advantages and disadvantages associated with the development of inbound and domestic tourism in the region, as well as prerequisites for the creation of a tourism cluster in the Kostanay region, were determined. It is concluded that the impeding factor in the creation of an interconnected tourism system is the absence of a dialogue between the authorities and the business community. Dialogue channels should be improved in order to further diversify Kazakhstan regional economies through the creation of tourism clusters.
\end{abstract}

\begin{abstract}
KEY WORDS
economic structure, tourism, domestic tourism, inbound tourism, cluster development, tourism cluster, clustering of industrial regions, synergy effect, export tourism potential
\end{abstract}

\section{FOR CITATION}

Bozhko, L.L., Leskova, L.G., Mukumov, A.A. (2021)

Prerequisites for the creation of a tourism cluster in the Kostanay region. R-economy, 7(2), 111-122. doi: $10.15826 /$ recon.2021.7.2.010

\section{Предпосылки создания туристского кластера в Костанайской области}

\author{
Л.Л Божко, Л.Г. Лескова $\bowtie$, А.А. Мукумов \\ Рудненский индустриальный институт, Рудный, Казахстан; e-mail: lleskova@mail.ru
}

\begin{abstract}
АННОТАЦИЯ
Актуальность. В условиях возрастающей конкуренции на рынке товаров и услуг структура национальной и региональной экономики Казахстана должна быть изменена, чтобы туризм стал мощным двигателем экономики. Формирование жизнеспособной системы географически смежных взаимосвязанных и взаимодополняющих компаний невозможно без соответствующей стратегии, в основе которой лежит комплексная оценка туристического потенциала. Цель исследования. Выявить предпосылки для формирования туристического кластера в регионе на основе кластерной стратегии, обеспечивающей создание эффективной системы управления. Данные и методы. Экономика Костанайской области оценивалась с использованием традиционных методов экономического анализа, таких как группировка и сравнение. C помощью SWOT-анализа определены преимущества и недостатки, а также угрозы и возможности, связанные с фор-
\end{abstract}

\section{КЛЮЧЕВЫЕ СЛОВА}

структура экономики, туризм, внутренний туризм, въездной туризм, кластерное развитие, туристский кластер, кластеризация индустриальных регионов, синергетический эффект, экспортный потенциал туризма 
мированием туристического кластера в Костанайской области. Использовалась официальная информация, предоставленная Бюро национальной статистики Агентства стратегического планирования и реформ Республики Казахстан. Результаты. Проведенный анализ валового регионального продукта Костанайской области и его доли в республиканских объемах подтвердил, что структура экономики региона может быть изменена путем создания туристического кластера на основе системы взаимодействующих и взаимодополняющих предприятий. Развитие туристического кластера увеличит объем услуг, связанных с размещением въезжающих и внутренних туристов. Выводы. Определены преимущества и недостатки, связанные с развитием въездного и внутреннего туризма в регионе, а также предпосылки для создания туристического кластера в Костанайской области. Сделан вывод о том, что сдерживающим фактором в создании взаимосвязанной туристической системы является отсутствие диалога между властью и бизнес-сообществом. Каналы диалога должны быть улучшены с целью дальнейшей диверсификации казахстанских региональных экономик за счет создания туристических кластеров.

\section{ДЛЯ ЦИТИРОВАНИЯ}

Bozhko, L.L., Leskova, L.G., Mukumov, A.A. (2021)

Prerequisites for the creation of a tourism cluster in the Kostanay region. R-economy, $7(2), 111-122$. doi: $10.15826 /$ recon.2021.7.2.010

\section{Introduction}

Tourism is increasingly becoming one of the leading and dynamically developing industries in all countries. Tourism contributes to the development of key economic sectors, such as transport, telecommunication services, construction, agriculture, production of consumer goods, etc. In addition, tourism ensures the inflow of foreign currency, thus increasing tax revenues to the budget and decreasing the unemployment rate.

Kazakhstan occupies a favourable geopolitical position and possesses significant natural recreational resources, objects of world cultural and historical heritage (11 objects are included in the UNESCO World Cultural Heritage List) and unique natural diversity. Therefore, this country enjoys a great potential for developing new tourism products and becoming a major player in global tourism ${ }^{1}$.

However, the tourism industry here is currently developing at a moderate pace, having little socio-economic impact on the national scale. In order to increase the inflow of tourists to the Republic of Kazakhstan, it is necessary to create favourable conditions for tourism development by both reducing the existing barriers and applying an efficient strategic planning of the industry. The realisation of these aims requires a large-scale and responsible state policy, which should, on the one hand, comply with global developmental trends, and, on the other, ensure the effective integration of the national and regional priorities.

Cultural heritage of Kazakhstan in the UNESCO list (2020). ARSLOGISTIK.RU. Taken from the source: https:// arslogistik.ru/bez-rubriki/kulturnoe-nasledie-kazahstana-v-spiske-yunesko.html
Issues concerned with tourism development in the context of individual regions require particular attention. The current weak diversification of regional economies and the lack of cluster initiatives are the obstacles for tourism to become a significant source of GRP growth.

It is common knowledge that cluster technologies have a significant impact on the development of regional economies. A definition of cluster policy was proposed by Markov, Kurmashev and Nizkovsky (2017), who concluded that "the cluster policy is used as an umbrella term for various approaches aimed at creating and supporting network associations of enterprises". Having generalized foreign approaches to the definition of the cluster concept, Kokareva concluded that "a cluster is a spatial form of organisation of productive forces, factors of production and public (economic and social) relations. Any cluster has the following characteristics: geographic localization; specialization of manufacturing firms; diversity and plurality of participants, their interdependence and complementarity; competition and cooperation" (Kokareva,2008).

Furre (2008) emphasized the importance of the impact of clusters on the economy and, in this regard, the need for a comprehensive study of the concept of cluster policy and its components. The researchers see a cluster in terms of "a geographically close group of interconnected companies and associated institutions in a particular area, related by common features and complementarities". In turn, the cluster policy includes all policies aimed at creating, mobilizing or strengthening a specific cluster; using clusters to improve efficiency.

In this article, we focus on the economy of the Kostanay region, the poorly-diversified structure 
of which is of an industrial and agricultural nature. Similar to all post-Soviet economies, the Kostanay region faces the challenge of economic disproportionality. Our study aims to identify prerequisites for creating a tourism cluster in the region and to develop recommendations for boosting cluster initiatives in the tourism industry.

To this end, the following objective were formulated:

- to analyse the economic state of the Kostanay region;

- to identify the advantages and disadvantages in the regional development to reveal potential threats associated with the creation of a tourism cluster and to develop the corresponding measures;

- to develop a set of recommendations for the implementation of a tourism development strategy in the Kostanay region.

\section{Literature Review}

Numerous studies have addressed problems of regional clusters. Thus, Brakman and van Marrewijk (2013) identified reasons for the inefficiency of a cluster policy: a lack of an accurate definition of the concept of cluster and difficulties in outlining the cluster boundaries. Corrado, Martin and Weeks (2005) proposed a methodology for endogenous selection of regional clusters by a multidimensional stationarity criterion. Within this approach, the number and composition of clusters are determined by pairwise criteria of regional differences in the per capita output.

Of particular interest is a study by Kozonogova (2018), which assessed the impact of a cluster policy on the quality of governance, including such tasks as improved quality of life in the population residing in the territory where the cluster is formed; investment attraction; the development of small and medium businesses; promotion of international scientific and technical cooperation. As a result, a relationship between the cluster, the level of average wages in the region and the level of investment in fixed capital was revealed.

Ketels (2014), as well as Steiner and Hartmann (2001), confirmed that the development of a cluster is closely related to changes in the region's economic indicators. Among the most significant criteria affecting the efficiency of a cluster policy were found to be the location of a cluster, its specialization, size, etc.

When analysing the impact of economic clustering on regional development, Kutsenko and Meissner (2013), argued that "the cluster approach makes innovation policies more systemic by coordinating measures aimed at supporting the attempts of various participants towards connecting the most promising localized industries".

Specific features of economic clustering in the Republic of Kazakhstan and the Russian Federation were identified in publications by Turgel, Bozhko and Pracheva (2019) and Pilipenko (2007). The authors confirmed the efficiency of merging clusters with special economic zones in the Republic of Kazakhstan. The authors also proposed criteria for classifying clusters, which include the year of cluster formation, the number of cluster members and the specialization and role of the cluster in the regional strategy of socio-economic development.

A group of research works was devoted to specific features of clusters. Thus, a study by Turgel, Bozhko and Bazhenova (2020) focused on the development of a metallurgical cluster in the Republic of Kazakhstan, while Kireeva (2018), Bozhko and Sapanova (2020) studied prerequisites for the creation of a digital cluster here to assess the role of digitalization in the region's sustainable development. Kulikova, Okovitaya and Surzhko (2021) considered the creation of agro-industrial clusters.

In addition, researchers investigated the development of tourism clusters (Cihan, 2003). Myakshin, Shaparov and Tikhanova (2021) identified the following conditions for the formation and development of regional tourism clusters: the presence of a potential for tourist inflow (natural-geographical and climatic characteristics of the territory) and the presence of objects of cultural and historical heritage and tourism infrastructure. The researchers proved the possibility of using a balanced system of indicators as a tool for identifying factors of tourism potential and a mechanism for coordinating the main interests of tourism actors.

Velichkina (2014) noted that the development of regional tourism is closely related to the tourism infrastructure, which either acts as a factor impeding the development of the industry, or determines the positive dynamics of the tourist and recreational sphere. Rabkina, Pavlova and Valko (2020) investigated the development of industrial tourism and emphasized the role of the local community, business and industrial heritage in the creation of tourism clusters.

Lee, Jang and Jinwon Kim (2020) argued the importance of considering tourism clusters in the context of intraregional and interregional in- 
teraction. The role of agglomerations in the development of the tourism industry was studied in the works by Li and Liu (2021). Kudryavtseva and Skhvediani (2018) studied the development of tourism in Russian regions and confirmed the presence of positive agglomeration effects arising from a higher cluster specialization. A positive relationship was revealed between the level of cluster specialization in the region and the GRP.

The questions of strategic tourism management were studied by $\mathrm{K}$. Turdibekova and Ibrokhimova (2020). Using the tools of strategic analysis, the authors identified problems in the sustainable development of the tourism industry and a lack of mechanisms supporting the growing demand for quality tourism services.

According to Bozhko (2020), the formation of tourism clusters in the northern regions of the Republic of Kazakhstan have a significant potential for improving the economic structure and socio-economic development, including the quality of life. However, despite these positive effects, the creation of tourism clusters in the northern $\mathrm{Ka}$ zakhstan regions have little priority for the local administrations and business communities.

The conducted literature review shows that numerous studies have addressed the problem of economic clusters and their role in regional development. However, there is a lack of research devoted to the issues of building communications and consolidating the efforts of authorities, business communities and population in the process of forming tourism clusters to promote regional diversification.

\section{Data and Methods}

The current state of the Kostanay region economy was assessed by conventional methods of economic analysis, such as grouping and comparison. SWOT analysis was used to determine the advantages and disadvantages, as well as the threats and opportunities associated with the formation of a tourism cluster in the Kostanay region. The strengths of the strategic approach in terms of identifying prerequisites for the development of tourism in the region are as follows:

- creation of conditions for long-term development and decision making, taking into account strategic aims;

- use of mechanisms for consolidating the efforts of local administrations, business communities and population, necessary for regional economy diversification;
- strengthening the relationship between the administration and the general public through a comprehensive discussion of the benefits of using cluster technologies.

The following specific features of the research design should be highlighted.

In Kazakhstan, the questions of creating clusters are managed at the national level, and the studied region is not included in the list of priority territories for the creation of tourism clusters (as reflected in the Concept for the Development of the Tourism Industry of the Republic of Kazakhstan until 2023). Therefore, we consider it expedient to analyse the opportunities and threats at different levels of the socio-economic system, including international, national, sectoral and inter-sectoral levels.

Advantages and disadvantages are summarised on the basis of the most significant factors determining prerequisites for tourist inflows, including the natural-geographical and climatic characteristics of the territory; the level of the tourism infrastructure; cultural heritage; the presence of sports, medical and industrial facilities; the interest of the local administration and business community in the development of tourism.

SWOT analysis was used to investigate the relationships between the authorities, businesses and population aimed at forming tourism clusters. An integral part of the study was a predictive analysis of the created tourist routes in the region.

The data sources were the official websites of the Bureau of National Statistics of the Agency for Strategic Planning and Reforms of the Republic of Kazakhstan and the Regional Statistics Office of the Kostanay region; normative documents of the Republic of Kazakhstan regulating tourism activities in Kazakhstan and its regions; programme documents of national and regional authorities.

The study proceeded through four logically related stages. The first stage analysed the economy of the Kostanay region in the context of its further diversification and development of the tourism industry. The second stage was a SWOT analysis of the tourism industry in the region under study. The third stage was devoted to the creation of a tourism cluster in the Kostanay region. This stage was considered from the standpoint of heterogeneity of enterprises that interact with each other, including value-added enterprises, academic and research structures, non-profit companies and administrative institutions. The number of participants in the tourism cluster should 
provide a positive effect of cluster interaction and coordination of activities on the collective promotion of goods and services in the domestic and foreign markets, etc. The fourth stage calculated the efficiency of the creation of a tourism cluster in the Kostanay region and proposed a set of recommendations for the implementation of a tourism strategy in the region.

\section{Results}

The conducted analysis of changes in the gross domestic product (GDP) of the Republic of Kazakhstan and the gross regional product (GRP) of the Kostanay region (in current prices) in 2019 compared to that in 2006 shows an increase in the studied indicators. Thus, the GDP of the Republic of Kazakhstan increased by an average of 6.8 times, while the GRP of the Kostanay region by 6.3 times. Undoubtedly, the observed GDP and GRP growth was largely associated with inflation. The analysis of the rate of inflation growth in the considered period showed its significant increase (the level of inflation in the Republic of Kazakhstan in 2019 compared to 2006 increased by 8.3 times, in the Kostanay region - by 14 times). Accordingly, the ratio of the inflation growth to the GDP growth rate in the considered period in the Republic of Kazakhstan was 1.2 times, in the Kostanay region - 2.2 times.

At present, attempts are being undertaken to diversify the economy of the Kostanay region from an agricultural to processing type. The share of the gross value added (GVA) manufacturing in the GRP increased by $7.3 \%$ in 2019 compared to 2006, while the share of GVA in the agricultural sector decreased by $6.7 \%$.
The development of the mining and metals complex is a priority area. More than 700 enterprises, which employ about 45,000 people, are engaged in the production of industrial products. The mining and metals sector accounts for more than $40 \%$ of the region's total industrial production. The region produces more than $60 \%$ of the Republic's iron ore products, $100 \%$ of iron ore pellets and asbestos ${ }^{2}$.

The region is implementing programmes aimed at solving current and future tasks of strategic development, including green economy, infrastructure development, energy conservation and alternative energy sources.

Investment projects are mainly implemented in system-forming traditional enterprises, which create the region's industrial basis. An analysis of the dynamics of registered legal entities in the Republic of Kazakhstan and in the Kostanay region shows no correlation in terms of this indicator (Table 1).

The data presented in Table 1 indicate that, during 2006-2019, the number of legal entities in Kazakhstan increased by 3.6 times. In comparison, in the Kostanay region, this number increased only by 2 times. This trend had a negative impact on the region's GRP. In addition, the number of medium and large enterprises in the Kostanay region decreased by $3 \%$ and $47 \%$, respectively. At the same time, the number of small enterprises increased by 2.1 times.

Thus, our results indicate that the diversification of the Kostanay region economy should be

2 Regions of Kazakhstan in 2019. Statistical yearbook. 456 pages Available at: https://stat.gov.kz/edition/publication/ collection

\section{Analysis of the number of registered legal entities in the Republic of Kazakhstan}

Table 1 and in the Kostanay region

\begin{tabular}{|c|c|c|c|c|c|c|}
\hline \multirow[t]{2}{*}{ Enterprise type } & \multicolumn{5}{|c|}{ Period / years } & \multirow{2}{*}{$\begin{array}{l}\text { Ratio of growth rates in } \\
2019 \text { compared to } 2006(\%)\end{array}$} \\
\hline & 2006 & 2008 & 2009 & 2014 & 2019 & \\
\hline Total registered legal entities in Kazakhstan: & 120862 & 208396 & 298028 & 353833 & 433774 & by 3.6 times \\
\hline small enterprises & 113730 & 202158 & 290112 & 344994 & 424796 & by 3.7 times \\
\hline medium enterprises & 4656 & 4213 & 5544 & 6364 & 6490 & 39.3 \\
\hline large enterprises & 2476 & 2025 & 2372 & 2475 & 2488 & 0.5 \\
\hline $\begin{array}{l}\text { Total registered legal entities in the Kostanay } \\
\text { region: }\end{array}$ & 7016 & 9540 & 12163 & 13153 & 14182 & 2.0 times \\
\hline small enterprises & 6501 & 9121 & 11747 & 12741 & 13789 & by 2.1 times \\
\hline medium enterprises & 298 & 275 & 294 & 289 & 289 & -3.0 \\
\hline large enterprises & 217 & 144 & 122 & 123 & 104 & -47.9 \\
\hline
\end{tabular}

Source: Compiled by the authors on the basis of the statistical yearbook of Kazakhstan Regions in 2019. Retrieved from https:// stat.gov.kz/edition/publication/collection 
aimed at expanding the non-resource sector. In our opinion, it is the tourism cluster (considered as the concentration within one limited territory of interconnected enterprises and organisations engaged in the development, production and sale of tourism products, as well as activities adjacent to the tourism industry and recreational services) that could play a role in the development of entrepreneurship in the region, including small and medium businesses.

As a diversification factor in the Kostanay region economy, prerequisites for the creation of a tourism cluster should be considered, with a particular focus on the inbound and domestic tourism. Trends in the development of inbound and domestic tourism, which allows the export of tourist services in Kazakhstan and in the Kostanay region are presented in Table 2.

Positive trends in the development of tourism in Kazakhstan and its regions are evidenced by a comparative analysis of the number of serviced tourists who entered Kazakhstan and the Kostanay region. In general, the number of tourists who entered Kazakhstan increased by $71.8 \%$ in 2019 compared to 2012, while in the Kostanay region by 3.05 times. This increase in the number of incoming tourists is associated with a favourable geographical location of the Kostanay region, which is situated in the north of Kazakhstan. The Kostanay region borders with three regions of the Russian Federation (Orenburg, Chelyabinsk and Kurgan regions), whose population maintains not only friendly, but also family relations. In addition, the fall of the Iron Curtain and the unification of Germany led to the outflow of more than 700,000 Germans to their historical homeland ${ }^{3}$,

3 The Demographic Yearbook of Kazakhstan. 276 p. Retrieved from https://stat.gov.kz/edition/publication/collection who maintain relations with former compatriots and relatives living in Kazakhstan.

Prerequisites for the development of tourism in the Kostanay region were assessed by a SWOT analysis, which identified advantages and disadvantages associated with the creation of a tourism cluster (Table 3 ). In addition, we determined possibilities for increasing the economic attractiveness of tourism development, which is expressed in an increase in tax revenues and the number of jobs, an increase in the quality of life and investment attraction.

The study showed that tourists are showing great interest in the Kostanay region. However, at present, there are no projects related to the development of industrial tourism. For businessmen interested in the development of industrial enterprises, special tours should be organized attract investments in new production.

In the region, the issues of supporting the creation of new tourist routes are poorly resolved. For example, Dest-Thor, the traditional and popular international festival of ancient technologies and cultural communications in memory of Thor Heyerdahl has not found adequate infrastructure support. Another problem the unsatisfactory state of the region's roads.

As a result of the analysis, the following priorities for the development of tourism in the Kostanay region were determined:

1) establishing a constructive dialogue between the government and the business community;

2) improving the Master plan for the development of tourism in the region and linking it with the plan of social and economic development. In particular, these documents should take into account the existing tourist facilities and describe the transport infrastructure connecting them with the place of the beginning of the trip.

Table 2

Comparative analysis of changes in the number of tourists in Kazakhstan and the Kostanay region by inbound and domestic destinations, thousand people

\begin{tabular}{|l|c|c|c|c|}
\hline \multirow{2}{*}{ Region } & \multicolumn{2}{|c|}{$\begin{array}{c}\text { Number of inbound foreign and local tourists, } \\
\text { thousand people }\end{array}$} & $\begin{array}{c}\text { Absolute deviation, } \\
\text { thousand people }\end{array}$ & $\begin{array}{c}\text { Relative } \\
\text { deviation, \% }\end{array}$ \\
\cline { 2 - 5 } & $\mathbf{2 0 1 2}$ & $\mathbf{2 0 1 9}$ & \\
\hline \multicolumn{5}{|c|}{ Inbound tourism } \\
\hline Republic of Kazakhstan & 519.2 & 891.9 & 12.7 & by 3.05 times \\
\hline the Kostanay region & 5.9 & 18.0 & 1880.5 & 75.0 \\
\hline \multicolumn{5}{|c|}{ Domestic tourism } \\
\hline Republic of Kazakhstan & 2507.0 & 4387.5 & 27.0 & 17.8 \\
\hline the Kostanay region & 147.7 & 174.1 & \\
\hline
\end{tabular}

Source: Compiled by the authors on the basis of the statistical yearbook of Kazakhstan Regions in 2019. Retrieved from https:// stat.gov.kz/edition/publication/collection 
SWOT analysis of tourism development in the Kostanay region

Table 3

Internal Environment

Advantages

\section{Disadvantages}

Natural-geographical and climatic characteristics of the territory

The presence of a nature potential, which can be used as a trigger of tourism growth in the Kostanay region (forests, lakes, rivers, rocks, reserves; a variety of landscapes, which belong to the natural areas well-defined in a latitudinal direction - forest steppe, steppe, semi-desert (desert steppes and deserts); balneological sources, water reservoirs and more). An opportunity to develop year-round trophy hunting

Favourable geographical location: the Kostanay region is located in the north of Kazakhstan and borders three regions of the Russian Federation

\section{Development of a tourism infrastructure}

Well-developed and diverse transport infrastructure (railways and highways connecting all regions of Kazakhstan and Russia); a modernised airport, receiving Kazakhstan and international aircrafts (German, Turkish, Belarusian, Russian, etc.). The possibility of purchasing tickets for a plane, train and bus online

The reconstructed airport runway allowing an increased number of passenger and cargo flights. The reconstruction in the amount of 4.5 billion tenge was funded by the Republican budget.

The presence of about 30 hotels in the regional centre

Regional tourist exhibitions "Kostanay. Tourism 2017" and "Kostanay. Tourism 2019", which allow entrepreneurs engaged in the tourism sector to expand their knowledge of the tourism potential of the Kostanay region

Two higher educational institutions train specialists in the specialty "Tourism Manager"; one college train in the following specialties: assistant administrator, service manager, waiter, barman

\section{Presence of cultural heritage}

Archaeological finds testifying to the history of Kazakhstan and the Kostanay region (as a resource of knowledge)

The presence of cultural objects such as theatres, museums and libraries

\section{Availability of sports, medical and industrial facilities}

Sports facilities are built in all settlements of the region (stadiums, sports grounds, sports arenas, ice stadiums, swimming pools, motorcycle tracks, etc.)

Availability of facilities for the organisation of health and wellness tourism, providing services not only to Kazakhstan citizens, but also to Russian and German citizens.

The presence of large mining enterprises allowing industrial tou-rism and development of a culture of mining (the first pelletising factory built in the USSR; unique iron ore quarries, etc.)

Interest of local administration and business community in the development of tourism

A master plan for the development of the tourism industry in the Kostanay region until 2022 has been developed, as well as a plan for the implementation of the master plan for the development of the tourism industry in the Kostanay region until 2022.
A large length of roads with a poor road surface. A lack of public places meeting modern requirements. A lack of small aircraft communication that could take tourists to etc.

Unsatisfactory condition of airport buildings, railway and automobile stations, with a limited range of services

Most hotels fail to meet the requirements of modern travellers (old uncomfortable rooms, low level of service)

Entrepreneurs engaged in breeding domestic animals traditional and valued by the Kazakh indigenous population (camels, horses, sheep, goats) are poorly attracted to participate in regional tourism exhibitions. Absence of a register of craftsmen who have preserved the technologies of leather dressing, weaving felt, sewing, making household goods from ceramics and wood

Educational institutions do not provide training of guides, tour operators, hotel and restaurant managers In 2019, only 26 mid-level and 21 top-level specialists were trained*.

In the region, there are only 4 tour operators, whose services are limited to outbound tourism in most cases

The absence of a unified strategy for the use of materials from archaeological research studies and the creation of tourist routes on their basis

The existing sports facilities are poorly used for international competitions

The absence of a register of health and wellness organisations that provide services to citizens from nearby and remote countries. There is no single advertising strategy 
End of Table 3

\begin{tabular}{|l|}
\hline \multicolumn{1}{|c|}{ Opportunities } \\
\hline \multicolumn{1}{|c|}{ International } \\
\hline $\begin{array}{l}\text { Development of integration processes; reduction of visa restrictions; } \\
\text { development of international tourism with a consequent increase in } \\
\text { the number of international arrivals and income from internation- } \\
\text { al tourism; growing tourist demand in developed foreign markets } \\
\text { such as the People's Republic of China, the Republic of India and the } \\
\text { Russian Federation; relatively high and stable demand in developed } \\
\text { foreign markets such as Europe; growing tourism supply from deve- } \\
\text { loping destinations }\end{array}$ \\
\hline $\begin{array}{l}\text { Standards of the World Tourism Organisation QUEST, which make } \\
\text { it possible to develop a Destination management organization and } \\
\text { improve the quality of the tourism industry }\end{array}$
\end{tabular}

\section{National level}

Economic instability in developed markets such as Europe and the United States of America, leading to increased consumer price sensitivity, which in turn poses a serious threat to premium tourism products

The National Development Plan of the Republic of Kazakhstan until $\quad$ Low share of tourism in the GDP

2025 defines the development of domestic tourism as a key task of the national priority "Building a diversified and innovative economy"

Favourable geostrategic location of Kazakhstan; rich historical and cul- A lack of coordination of interested government agencies tural heritage included in the UNESCO World Cultural Heritage List, to implement an integrated approach to the development and the State List of Historical and Cultural Monuments of Republican of the tourism industry, including cultural and sports areas Significance

Positive and productive intercultural relations, contributing to the promotion of national and interstate understanding, including the promotion of socio-cultural, ethnographic, medical, sports, culturaleducational, scientific, children and youth and other types of tou-rism which contribute to the promotion of the values of the national idea "Мәңгілік Ел"

Reimbursement of the costs of private business in the construction, reconstruction and equipping of tourist facilities, which allows attracting private investment in the development of tourism infrastructure

A lack of qualified personnel in the tourism sector

Reduction of visa barriers in the Republic of Kazakhstan. Citizens of more than thirty states are allowed to stay in Kazakhstan without opening a visa for a period of 15-90 days

Promotion of the Silk Road brand

The current policy to improve the infrastructure of checkpoints across the State Border of the Republic of Kazakhstan

The implemented state programme "Digital Kazakhstan", which contributes to the growth of the use of various technological applications in all sectors related to tourism

\section{Industry level}

The Concept for the Development of the Tourism Industry of the Re- $\quad$ The Concept for the Development of the Tourism Induspublic of Kazakhstan until 2023 has been developed, with a focus on try of the Republic of Kazakhstan until 2023 includes a the implementation of anchor tourism projects in the most promising limited number of regions, where cluster initiatives are areas of tourism clusters planned

The State Programme for the Development of the Tourism Industry in $\quad$ Low attractiveness of the tourism industry for external the Republic of Kazakhstan for 2019-2025 has been developed investors

A lack of a competitive environment in the industry and a strong dependence on business tourists. Tourism services, including hotel accommodation, are limited and poorly regulated

state programme for the development and integration lic of Kazakhstan until 2020 did not find continuation in other programme documents, slowing down th development of transport communications (air, ground)

The absence of a policy aimed at the development of intersectoral complexes based on the integration of production ties

Source: Compiled by the authors

* Education in the Republic of Kazakhstan / Statistical collection / in Kazakh and Russian / 248 p. Retrieved from http: //www. $\underline{\text { stat.gov.kz }}$ 
As a result of the analysis of the possibilities of pursuing an active cluster policy, taking into account the existing socio-economic situation of the region in the spheres of tourism development, small and medium enterprises, investment and innovation activities, education and science, it can be concluded that the existing competitive advantages of the Kostanay region can be considered as a favourable basis for the creation and development of a tourism cluster in the region.

The priority steps in the formation of a tourism cluster should be:

- conducting an in-depth analysis of the competitiveness of the tourism sector of the Kostanay region, including studying the potential of economic entities existing in the tourism sector, their products and services, the innovative capabilities of educational institutions and scientific organisations, as well as the investment and human potential of the region to create a tourism cluster. It is also necessary to identify possible mechanisms and forms of obtaining financial support, implementing public-private partnership projects, etc.;

- promoting and organising an active public discussion of the advantages of the cluster approach as an effective tool for active tourism policy at the regional level;

- preparing promising investment sites, including providing them with engineering and transport infrastructure to attract direct investment in the tourism sector.
The proposed scheme of the tourism cluster of the Kostanay region (Fig. 1) reflects the interaction of its participants. At the same time, the authors believe that the regional authorities should become the core of a viable tourism cluster, along with the business community. It is the regional authorities that are called upon to ensure the implementation of the state policy of the executive branch in combination with the interests and needs of the development of the respective territory.

Our calculations show that the occupancy rate of hotels, in the absence of tourist routes (only cultural and sports events are taken into account) in 2019 was $28.7 \%$, in 2020 this indicator decreased by $0.8 \%$ (Table 4 ).

In our opinion, under an optimistic scenario, up to 10 tourist routes can be created annually within the tourism cluster, provided the presence of effective interaction between the authorities, businesses and public structures.

An increase in the number of routes will raise the occupancy rate of hotels, implying an increase in the volume of services provided. Under an average number of participants in one route of 15 people and its weekly duration, this route will serve up to 782 people at the places of accommodation. The annual growth in the number of served tourists at the level of $11-13 \%$ with $100 \%$ hotel occupancy will make it possible to triple the volume of services provided in the places of accommodation.

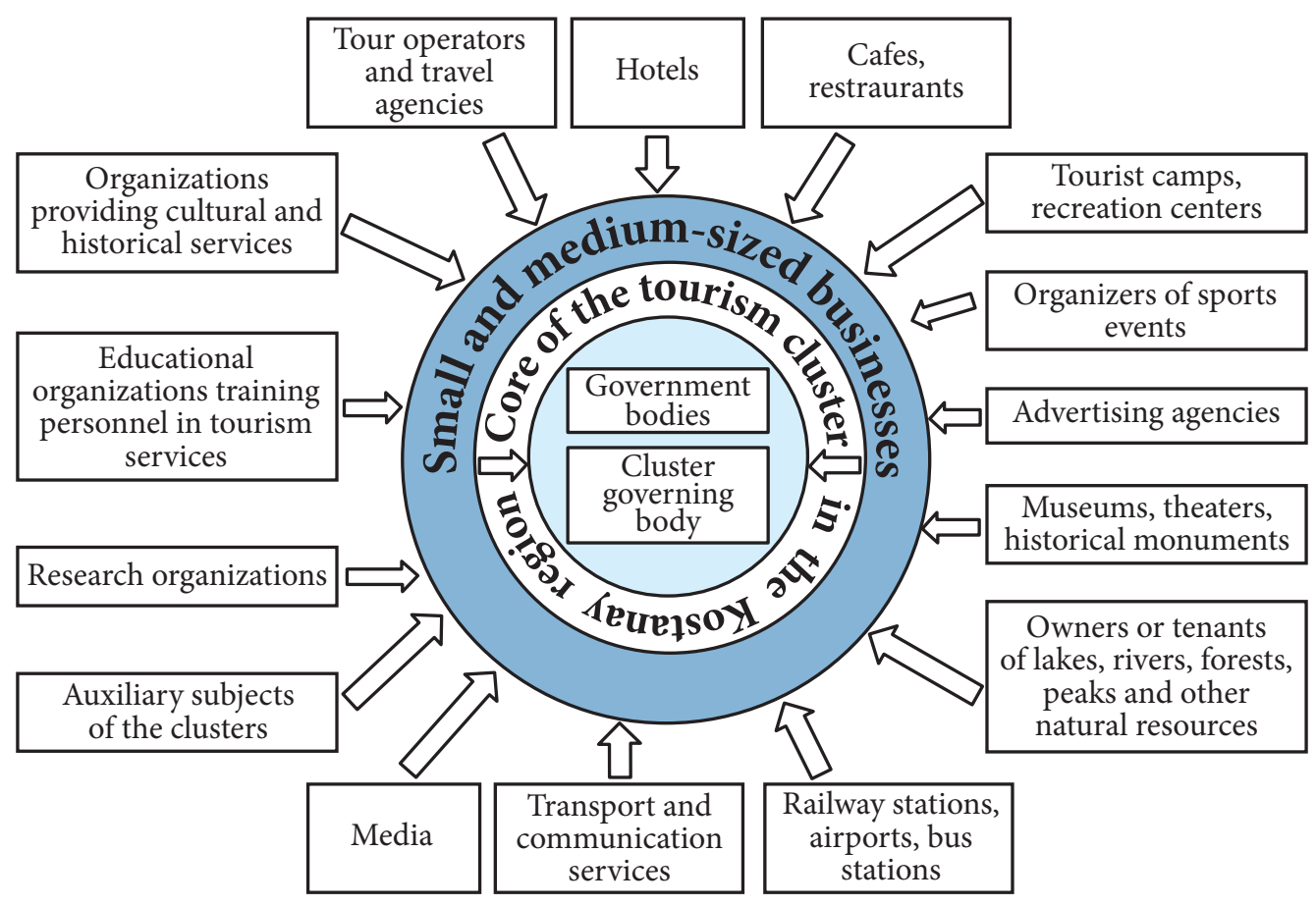

Figure 1. Author's scheme of creating a tourism cluster in the Kostanay region 
Forecast of the volume of services associated with accommodation, taking into account

Table 4 the creation of new tourist routes

\begin{tabular}{|c|c|c|c|c|c|c|c|c|c|}
\hline \multirow[t]{2}{*}{ Indicator name } & \multicolumn{2}{|c|}{ Actual values } & \multicolumn{2}{|c|}{ Deviation } & \multicolumn{5}{|c|}{ Expected values } \\
\hline & 2019 & 2020 & absolute & relative, $\%$ & 2021 & 2022 & 2023 & 2024 & 2025 \\
\hline 1 & 2 & 3 & 4 & 5 & 6 & 7 & 8 & 9 & 10 \\
\hline $\begin{array}{l}\text { Volume of services provided at the } \\
\text { places of accommodation (worst-case } \\
\text { scenario), million tenge }\end{array}$ & 1727.2 & 1837.8 & 110.6 & 106 & 1853.2 & 1899.6 & 2054.1 & 2301.1 & 2610.0 \\
\hline Hotel occupancy (worst-case scenario), \% & 28.7 & 27.9 & -0.8 & 97 & 28.1 & 28.8 & 31 & 34.7 & 39.3 \\
\hline $\begin{array}{l}\text { The number of visitors served at the } \\
\text { places of accommodation (optimistic } \\
\text { scenario), people }\end{array}$ & - & - & - & - & 239519 & 245384 & 264934 & 296214 & 335314 \\
\hline $\begin{array}{l}\text { The volume of services at } 100 \% \text { hotel } \\
\text { occupancy, million tenge }\end{array}$ & - & - & - & - & 6595.3 & 6595.9 & 6626.0 & 6631.6 & 6641.4 \\
\hline
\end{tabular}

Source: compiled by the authors

\section{Conclusion}

The synergistic effect obtained from the creation of tourist routes within the proposed tourism cluster indicates the need for consolidating the efforts of state authorities, businesses and the general population concerning further diversification of the region's economy. The creation of a tourism cluster in the Kostanay region should become a national idea. Only in this case, the regional authorities, business community and population will realise all the benefits of tourism development in the region. Taking into account medium- and long-term prospects of economic development and correlating the available historical, cultural, natural and landscape attractions, as well as industrial facilities, with the state of tourism and transport infrastructure, up to 10 tourist routes can be created annually within the tourism cluster.

At the same time, the main role is played by the availability of tourist resources with a relative compactness of their location, the degree of commercialization of resources, the level of development of horizontal ties between the subjects of tourism activities, transport accessibility in relation to the main sales markets.

\section{References}

1. Bozhko, L., Sapanova, R., Shtykova, I., \& Wijayanti, F. (2020) Creation of Digital Ecosystem in the Context of Region Sustainable Industrialization E3S Web of Conferences, 2020, 208, 03046. doi: $10.1051 / \mathrm{e} 3$ sconf/202020803046

2. Brakman, S., \& van Marrewijk, C. (2013). Reflections on cluster policies. Cambridge Journal of Regions, Economy and Society, 6(2), 217-231. doi: 10.1093/cjres/rst001

3. Cihan, T.V. (2003). Cluster theory of economic development. Teoriya i praktika upravleniya $=$ Management Theory and Practice, 5. (In Russ.)

4. Corrado, L., Martin, R., \& Weeks, M. (2005). Identifying and Interpreting Regional Convergence Clusters across Europe. The Economic Journal, 115 (502), 133-160. doi: 10.1111/j.0013$\underline{0133.2005 .00984}$

5. Furre, H. (2008). Cluster Policy in Europe - A Brief Summary of Cluster Policies in 31 European Countries. Oxford Research AS, Norway.

6. Ketels, C. (2013). Recent research on competitiveness and clusters: what are the implications for regional policy? Cambridge Journal of Regions, Economy and Society, 6(2), 269-284. doi: $\underline{10.1093 / \mathrm{cjres} / \mathrm{rst} 008}$

7. Kireyeva, A.A., Mussabalina, D.S., \& Tolysbaev, B.S. (2018). Assessment and identification of the possibility for creating clusters in Kazakhstan regions. Ekonomika regiona $=$ Economy of Region, 14(2), 463-473. doi: 10.17059/2018-2-10

8. Kokareva, M.S. (2008). Theoretical aspects of clusters formation: essence and classification. Ekonomika regiona = Economy of Region, S4, 136-148. (In Russ.) 
9. Kozonogova, E.A., Dubrovskaya, J., Goncharova, N., \& Elokhova, I. (2019). Does state cluster policy really promote regional development? The case of Russia. IOP Conference Series: Materials Science and Engineering, 497, 012044. doi: 10.1088/1757-899x/497/1/012044

10. Kudryavtseva, T.Y., \& Shvediani, A.E. (2018). Analysis of the relationship between cluster specialization and gross regional product. Nauchno-tekhnicheskie vedomosti SPbGPU. Ekonomicheskie nauki = Scientific and Technical Bulletins of St. Petersburg State Pedagogical University. Economic Sciences, 11(5), 66-73. (In Russ.) doi: 10.18721/JE.11506

11. Kulikova, M.A, Okovitaya, K.O., \& Surzhko O.A. (2021). Formation of agroindustrial clusters with integrated waste recycling. Mezhdunarodnyj nauchno-issledovatelskij zhurnal = International Research Journal, 2-1, 159-163. (In Russ.) doi: 10.23670/IRJ.2021.103.2.030

12. Kutsenko, E.S., \& Meissner, D. (2013). Key Features of the First Phase of the National Cluster Programme in Russia. Working papers by NRU Higher School of Economics. Series WP BRP "Science, Technology and Innovation". No. 11 / STI / 2013. Retrieved from https://publications.hse.ru/ mirror/pubs/share/folder/mfcuttkkwb/direct/86788676

13. Lee, Y-J.A., Jang, S. \& Kim, J. (2021). Tourism clusters and peer-to-peer accommodation. Annals of Tourism Research, 83, 102960. doi: 10.1016/j.annals.2020.102960

14. Li, Z., \& Liu, H. (2021). How tourism industry agglomeration improves tourism economic efficiency? Tourism Economics. doi: 10.1177/13548166211009116

15. Markov, L.S., Kurmashev, V.B., \& Nizkovskiy, A.Yu. (2017). Federal and regional cluster policy of the Russian Federation. Mir ekonomiki i upravleniya = World of Economics and Management, 17(4), 107-121. (In Russ.) doi: 10.25205/2542-0429-2017-17-4-107-121

16. Myakshin, V.N., Shaparov, A.E., \& Tikhanova, D.V. (2021) Improving the assessment of thetourist potential of the subjects of the Arctic zone of the Russian Federation. Ekonomika regiona = Economy of Region, 17(1), 235-248. (In Russ.) doi: 10.17059/ekon.reg.2021-1-18

17. Pilipenko, I. (2007). Cluster policy in Russia. Obshchestvo i ekonomika = Society and Economics, 8, 28-64. (In Russ.)

18. Rabkina, N., Pavlova, O., \& Valko, O. (2020). Prospects for Industrial and Post-Industrial Tourism in Kuzbass Coal Mining Cluster. E3S Web of Conferences, 174, 04018. doi: 10.1051/e3sconf $/ 20201740401$

19. Steiner, M., \& Hartmann, C. (2001). Looking for the invisible: material and immaterial dimensions of clusters. Presented at the Regional Studies Association Annual Conference on Regionalising the Knowledge Economy, London, United Kingdom.

20. Turdibekov, K., \& Ibrokhimov, N. (2020). Strategic Development of Tourism Taking into Account Regional Features of the Republic of Uzbekistan. Indonesian Journal of Law and Economics Review, 8, 12. doi: 10.21070/IJLER.2020.V8.523

21. Turgel, I., Bozhko, L. Pracheva, E., \& Naizabekov, A. (2019). Impact of Zones with Special Status on the Environment (Experience of Russia andKazakhstan). Environmental and Climate Technologies, 23(2), 102-113. doi: 10.2478/rtuect-2019-0058

22. Turgel, I., Bozhko, L., \& Zinovieva, E. (2019). Cluster approach to organization of special economic zones in Russia and Kazakhstan. R-Economy, 5(2), 71-78. doi: 10.15826/recon.2019.5.2.008

23. Turgel, I., Bozhko, L., \& Bazhenov, O. (2020). The evaluation methodology for the ecological and economic potential of the metallurgical cluster. Environmental and Climate Technologies, 24(1), 501-515. doi: $10.2478 /$ rtuect-2020-0031

24. Velichkina A.B. (2014). Evaluation of the development of tourism infrastructure in theregion. Ekonomicheskie i socialnye peremeny. Fakty, tendencii, prognoz = Economic and Social Changes. Facts, Trends, Forecast, 2(32), 239-250. (In Russ.) doi: 10.15838/esc/2014.2.32.18

\section{Information about the authors}

Larissa Bozhko - Doctor of Economics, Economics and Management Department, Vice-rector on academic affairs and research, Rudny Industrial Institute (50 Let Oktyabrya Str. 38, Rudny, 111500); e-mail: bogkoll@rii.kz, bozhkoll70@gmail.com

Liliya Leskova - Cand. Sci. (Economics), Head of the Center for DET and MOOC, Rudny Industrial Institute (50 Let Oktyabrya Str. 38, Rudny, 111500); e-mail: lleskova@mail.ru 
Adilbek Mukumov - Bachelor (Economics), System Administrator of the Center for DET and MOOC, Rudny Industrial Institute (50 Let Oktyabrya Str. 38, Rudny, 111500); e-mail: adilbekovich95@mail.ru

ARTICLE INFO: received March 21, 2021; accepted June 3, 2021

\section{Информация об авторах}

Божко Лариса Леонидовна - доктор экономических наук, доцент, кафедра экономики и менеджмента, проректор по учебной и научной работе, Рудненский индустриальный институт (111500, Казахстан, г. Рудный, ул. 50 лет октября, 38); e-mail: bogkoll@rii.kz, bozhkoll70@gmail.com

Лескова Лилия Гербертовна - кандидат экономических наук, руководитель ЦДОТиМООК, Рудненский индустриальный институт (111500, Казахстан, г. Рудный, ул. 50 лет октября, 38); e-mail: lleskova@mail.ru

Мукумов Адильбек Адильбекович - бакалавр экономики, системный администратор ЦДОТиМООК (111500, Казахстан, г. Рудный, ул. 50 лет октября, 38); e-mail: adilbekovich95@mail.ru

ИНФОРМАЦИЯ О СТАТЬЕ: дата поступления 21 марта 2021 г.; дата принятия к печати 3 июня 2021 г. 